ELK ASIA PACIFIC JOURNAL OF MARKETING \& RETAIL MANAGEMENT

ISSN 2349-2317 (Online); DOI: 10.16962/EAPJMRM/issn. 2349-2317/2018; Volume 9 Issue 4 (2018)

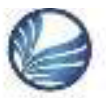

ELK

Asia Pacific Journals

www.elkjournals.com

\title{
CONSUMERS ATTITUDE TOWARDS T.V. COMMERCIALS - A STUDY BASED IN THE STATE OF GOA
}

\author{
DR. POURNIMA DHUME \\ Assistant Professor \\ Department of Commerce, \\ Faculty Block F, Goa University, Taleigao \\ Goa 403206 India \\ Email- pournima.dhume@unigoa.ac.in
}

\author{
DEEPA NAIK \\ Alumnus of Department of Commerce \\ Department of Commerce, \\ Faculty Block F, Goa University, Taleigao \\ Goa 403206 India \\ Email- naikdeepa1110@gmail.com
}

\begin{abstract}
Advertisement is an important element in the promotion of a product. Advertising is a form of mass communication (verbal and non-verbal) of information. Advertising is not only concerned with promoting the products but more importantly, it aims at making the customers buy the products and differentiating their products from that of others. Attitude is the way in which people perceive things and react to them. Responsiveness of the people towards T.V. commercials depends on their attitude towards the concerned T.V. commercial. Customer's attitude towards TV Commercials, Celebrity endorsement and different advertising appeals (humour, emotional, musical, rational appeal etc.) used in advertisements to make the advertisement more interesting for the consumers so that they remember the advertisement, think about it thus leading to the buying decision. This paper makes an attempt to examine attitude of people towards T.V. commercials, it further analyzes the role of celebrities in T.V. commercials and its impact on consumer buying behaviour. This study further determines the likeability among the advertising appeals in T.V. commercials among consumers. The findings of the study reveal that, people belonging to different categories of age group, gender, education level, etc. may have different attitude towards the T.V. commercials, so the advertisers while designing the advertisements should consider the attitude of people and design the advertisements accordingly to make the consumers to perceive the advertisement in a positive way. Advertisers can use celebrities effectively for endorsing their products and services. Advertisers should be careful while choosing the celebrities for endorsing their products; the endorsers should be selected based on the type of product to be advertised and the based on the target customers. Choosing the correct medium of advertisement for reaching the ultimate consumers is very vital as advertising products and services on any medium incurs cost, which needs to be compensated with increased revenue.
\end{abstract}

Keywords: Attitude, Celebrity, Commercials, Endorsement, TV

\section{INTRODUCTION}

Advertising means communicating and informing the people about the products 


\section{ELK ASIA PACIFIC JOURNAL OF MARKETING \& RETAIL MANAGEMENT}

ISSN 2349-2317 (Online); DOI: 10.16962/EAPJMRM/issn. 2349-2317/2018; Volume 9 Issue 4 (2018)

and services and thus influencing them to buy the products and services. Advertisement is an important element in the promotion of a product. Advertisements are important tools used by the companies for promoting their existing and the new products. Having a good product is not enough; in today's highly competitive and rapidly changing environment, applying innovative promotional techniques for promoting the products are very important. Advertising is not only concerned with promoting the products but more importantly, it aims at making the customers buy the products and differentiating their products from that of others. Advertising is a form of mass communication (verbal and non-verbal) of information. The advertisers or sponsors pay for the advertisements and usually aim at influencing people about the goods and services. Advertisements target large groups of people. It uses both verbal and non-verbal medium of communication like television, radio, newspaper, magazine, etc. The advertisements not only promote the tangible products like cell phones, cosmetics, detergents, etc. advertisements are also used for promoting intangible products like banking, insurance, health care services etc. Sometimes advertisements also inform people about legal notices, any social or religious events, etc. Merely having an advertisement is not enough, it is important that the advertisement reach the target audience. The advertisement reaches the target audience through various mediums/channels of communication. Mass media like Television, Radio and Newspaper connects with the millions of people across the country as well as the World.

\section{LITERATURE REVIEW}

There has been ample literature available on the Impact of TV Commercials on the buying behaviour of consumers. Several researchers have contributed to this field of study. The review of literature has been carried out by categorizing into three aspects viz; Attitude of consumers towards TV Commercials, Impact of Celebrity endorsement on consumer buying behaviour and Advertisement appeals.

\subsection{Attitude}

Attitude can defined as a behavior or opinion of a person towards a particular person, thing, situation etc. a person can 
ELK ASIA PACIFIC JOURNAL OF MARKETING \& RETAIL MANAGEMENT

ISSN 2349-2317 (Online); DOI: 10.16962/EAPJMRM/issn. 2349-2317/2018; Volume 9 Issue 4 (2018)

have a positive, negative or a neutral attitude towards anything, which he/she might express in different ways. An attitude is a hypothetical construct that represents an individual's degree of like or dislike for an item. (Chittithaworn, Islam and Thooksoon February 2011). T.V. commercials had more impact on the behaviour and attitude of children. The results also showed that age is an important factor for understanding the advertisements

[Ertike (2011),Narasimhamurthy (2014), Yasin et al (2013)Chithra \& Kothai (2014)]. Chittithaworn et al (2011), conducted an exploratory study in Thailand aimed at studying the relationship between the belief dimensions and attitude of viewers towards T.V. commercials, and found that viewers generally have negative attitude towards T.V. commercials. Informational benefits, negative contents and offensive belief dimensions were found significant in the study. Usman et al (2010) carried on a research in Pakistan with the objective to analyze the impact of culture on the attitude of people towards advertisements. It was found that Social integration, product information and hedonism have a significant impact on attitude towards advertisement. The findings further revealed that consumers are attracted towards exciting advertisements thus creating positive buying attitude. It was also found that advertisements that play a role in educating the children create a positive attitude towards advertisements. Guo et al (2008) examined the impact of cultural differences on the attitude of people towards T.V. commercials and they studied consumer attitude by considering various belief factors. The respondents for the study were the students from the universities of United Kingdom, China, and Hong Kong. Findings of the study showed that Hong Kong respondents had a favorable attitude whereas respondents from UK had unfavorable attitude towards advertising. Razzaque (2009) analyzed the responses based on the five factors such as overall liking, believability, objectivity of the product description, desire to purchase and promoting materialism. Anwar (2012) aimed at studying the young consumer's attitude and perception towards T.V. commercials and their impact on consumer purchase decisions. He also studied the consumer preference for different types of advertisement appeals and consumer attitude towards various types of endorsements. The findings showed that television is very influencing medium of 
ELK ASIA PACIFIC JOURNAL OF MARKETING \& RETAIL MANAGEMENT

ISSN 2349-2317 (Online); DOI: 10.16962/EAPJMRM/issn. 2349-2317/2018; Volume 9 Issue 4 (2018)

advertisement. It was found that the consumers preferred humorous advertisements to the other advertising appeals. The respondents preferred advertisements endorsed by film and sports celebrities to the advertisements that used experts as endorsers. Yarahmadi (2015) aimed at studying the differences in the perception of consumers towards television advertisements in Iran. The study revealed that, in most of the television advertisement there was significant difference in the perception of male and female respondents towards the four advertising adjectives i.e. informative, amusing, appealing and irritating advertising adjectives. Liligeto et al (2014) considered two medium of advertisements namely television, newspaper, and identified three factors that affected the perception of consumers towards television and newspaper advertisements. The three factors identified were advertising media, economic and social factors and personal characteristics. Findings revealed that, the perception of the consumers towards advertisement affect their buying decision.

\subsection{Celebrity Endorsement}

Celebrities are well-known individuals like Television stars, movie actors and actress, famous athletes, pop stars, entertainers, etc. McCracken (1989) defines a celebrity endorser as "any individual who enjoys public recognition and who uses the recognition on behalf of a consumer good by appearing with it in an advertisement". Using celebrities in advertisements can have positive influence on the consumers buying behavior, trustworthiness, remembrance of the message, product etc. Some of the studies in the area of celebrity endorsement in T.V. commercials are as follows: Abirami \& Krishnan (2015) aimed at studying consumer attitude towards celebrity endorsement. The study suggested that advertisers should use potential endorsers respected by people for endorsing advertisements. Pughazhendi et al (2011) carried on a study with one of the objective being to access the influence of celebrity endorsement. The study showed that celebrity endorsements have significant impact on brand recall and it has influence on consumer purchase decision. Hudha \& Hidayat (2009) analyzed the influence of celebrity attractiveness on customers brand choice and focused on studying the way in which customers perceive celebrity endorsed T.V. commercials. The findings showed that celebrity endorsed T.V. commercials attract the consumers positively. Thus, it 


\section{ELK ASIA PACIFIC JOURNAL OF MARKETING \& RETAIL MANAGEMENT}

ISSN 2349-2317 (Online); DOI: 10.16962/EAPJMRM/issn. 2349-2317/2018; Volume 9 Issue 4 (2018)

also influences the brand choice of the consumers. Radha \& P (2013) focused on analyzing the impact of celebrity endorsement on consumers purchase decision. Balakrishnan \& Kumar (2011) studied the impact of celebrity endorsement in advertisements on purchase decision of the consumers towards durable products. The study revealed that celebrity endorsement helps consumers in brand recall. Aziz et al (2013) examined the consumer attitude towards advertisements, brand and purchase intention of consumers by analyzing the impact on the advertising effectiveness created by celebrity credibility. The findings showed that as compared to the unknown celebrities famous celebrities were considered more credible and had positive impact on attitude of consumers towards advertisements, brand and purchase intentions. Rashid et al (2002) examined the consumers perceptions regarding celebrity endorsed advertisements and the impact of celebrity advertisements on the purchasing behavior of consumers. Respondents from Malays, Chinese, and India were considered for the study. The results showed that there was significant difference in the attitude of consumers from the three countries towards celebrity advertisements, perception of consumers towards product endorsement, credibility of celebrities and selection of brands. Overall, the results showed that celebrity advertisements influenced the purchase decision of the respondents. Kumar \& Hundal (2015) examined the perception of customers towards celebrity endorsement. Nine factors identified were attractiveness, trustworthiness, physical appearance, popularity, image/Goodwill, and reliability, negative role of celebrity, aspiration, and brand value. The results of the study were that attractiveness of the celebrities had a strong influence on the perception of consumers.

\subsection{Advertising Appeals}

Different advertising appeals (humor, emotional, musical, rational appeal etc.) used in advertisements to make the advertisement more interesting for the consumers so that they remember the advertisement, think about it thus leading to the buying decision. Different people might have different attitude towards the various elements/appeals used in the advertisement. Many researchers have studied the impact of various elements/appeals on the consumer's attitude towards T.V. commercials and 


\section{ELK ASIA PACIFIC JOURNAL OF MARKETING \& RETAIL MANAGEMENT}

ISSN 2349-2317 (Online); DOI: 10.16962/EAPJMRM/issn. 2349-2317/2018; Volume 9 Issue 4 (2018)

their buying behavior. Some of them are listed below: Mensah et al (2013) examined various advertising elements, which influenced consumer purchase decisions and their attitude towards such elements. It was found that most respondents preferred music/jingles used in advertisements and bar/party setting were the least preferred element. Farooq et al (2015) used college and university students as their respondents and analyzed whether comic factor used in T.V. commercials affected the buying behavior of the students. It was found that the buying behavior of the students was gender free, the results also showed that the comic factor affected the buying behavior of the students by grabbing their attention, interest, and desire to purchase the product. Ling et al (2010) identified the determinants of consumer's attitude towards advertising and it was found that credibility, informative, hedonic/pleasure and good for economy had positive impact on consumer's attitude towards advertising.

\subsection{Objectives of the Study}

The research objectives targeted for the present research are:

\subsection{To examine attitude of people} towards T.V. commercials.
2.2 To analyze the role of celebrities in T.V. commercials and its impact on consumer buying behavior.

2.3 To determine the likeability among the advertising appeals in T.V. commercials among consumers.

\section{ATtitude OF PEOPLE TOWARDS T.V. COMMERCIALS}

Attitude is the way in which people perceive things and react to them. Behavior of a person is very much dependent on the attitude of the person. Different people might behave differently in the same situation this is because different people perceive things differently and react accordingly. Attitude of a person can also depend on the belief, culture, etc. a person can have a positive, negative, or neutral attitude towards anything. Similarly, different people might have different attitude towards a T.V. commercial. Responsiveness of the people towards T.V. commercials depends on their attitude towards the concerned T.V. commercial. Therefore, it is important for the advertisers to know what people feel about their advertisements, what are the things people like to see in a T.V. commercial. In this paper, the attitude of people towards the T.V. commercial is 


\section{ELK ASIA PACIFIC JOURNAL OF MARKETING \& RETAIL MANAGEMENT}

ISSN 2349-2317 (Online); DOI: 10.16962/EAPJMRM/issn. 2349-2317/2018; Volume 9 Issue 4 (2018)

studied. Factor analysis is used to identify the factors that affect attitude of people towards T.V. commercials. The factors identified is again analyzed across the demographic profile of the respondents using One-Way ANOVA to see if there is any difference in the attitude of people across the demographic variables.

Table 1 represents the distribution of respondents across the demographic variables, viz., age, gender, education and present status. Maximum respondents i.e. $39 \%$ were from the age group of 21-25, $14 \%$ of respondents were from the age group of 26-30 and equal percentage of respondents were from the age group of 31-35. 9\% respondents were above 46 years of age. Three age groups i.e. 15-20, 31-35 and 36-40 had same percentage of respondents, which was $8 \%$. Further, the respondents have also been classified based on the educational qualification. Graduates formed $34 \%$ of the respondents, while $25 \%$ respondents were postgraduate. People with $10-12^{\text {th }}$ education qualification formed $15 \%$ of the total respondents. $11 \%$ respondents had professional degree while an equal number of respondents were less than $10^{\text {th }}$ educated. 3\% respondents had other educational qualification and only $1 \%$ was doctorate. Table 1 also displays the present status of the respondents. $41 \%$ of the respondents belong to the working class, while 39\% were students. Homemakers formed the $15 \%$ of the respondents, $4 \%$ respondents were unemployed, $1 \%$ of respondents were retired while there was no respondent from others category.

Figure 1 represents the medium of advertisement preferred by the respondents. Out of the total respondents maximum of $72.24 \%$ of respondents prefer television as a good medium of advertisement whereas only $3.34 \%$ respondents prefer radio as a good medium of advertisement, which is the least among all the four medium of advertisement. 8.13\% respondents preferred print media while $16.26 \%$ respondents preferred internet.

\section{Relationship between Medium of Advertisement Preferred and \\ Demographic Profile of Respondents}

To determine if there exists any relation between the medium of advertisement preferred and the demographic profile of respondent's chi-square test is used.

It is evident from Table 2 that, the null hypothesis is rejected at $5 \%$ significance 


\section{ELK ASIA PACIFIC JOURNAL OF MARKETING \& RETAIL MANAGEMENT}

ISSN 2349-2317 (Online); DOI: 10.16962/EAPJMRM/issn. 2349-2317/2018; Volume 9 Issue 4 (2018)

level. There exists a significant association between demographic variables and medium of advertisements preferred.

Further, to examine the attitude of people towards T.V. commercials factor analysis has been performed using principal component analysis. The factors were rotated using varimax rotation. The extraction method was based on eigen value greater than 1.00 for the selection of factors. Based on the results of factor analysis all the variables forming peoples attitude towards T.V. commercials were clubbed into four factors/attitude:

1. T.V. commercials are informative (referred as informative factor).

2. T.V. commercials are entertaining to watch (referred as entertaining factor).

3. T.V. commercials are annoying (referred as annoying factor).

4. T.V. commercials make the products and services costly (referred as costly factor).

KMO value is 0.747 and Bartlett's Test of Sphericity significance value is 0.000 , which is less than 0.05. Data collected is large enough and the responses are valid and significant for the concerned study.
Thus, factor analysis can be carried forward. (Table- 3)

Cronbach's Alpha values ranging between 0.689 and 0.869 indicate that the data is reliable. Keeping the Eigen value greater than one, four factors are extracted using SPSS. First factor explains $30.815 \%$ of the total variance. Second, third and fourth factors explain $17.635 \%, 11.640 \%$ and $8.302 \%$ respectively. All the factors together explain $68.391 \%$ of the total variance caused by the 14 variables. (Table- 4)

One-Way ANOVA : The attitude of people towards T.V. commercials were analyzed using one-way ANOVA to see if there is any difference in attitude across the demographic profile of the respondents.

Since the p-value is less than 0.05 in case of Informative, Annoying and Costly factors, the null hypothesis is rejected at 5\% significance level. Hence, there is significant difference in the attitude of people towards the T.V. commercials across the age group. In case of Entertaining factor, there is no significant difference in the attitude of people towards 
the T.V. commercials across the age group. (Table- 5)

Since p-value for all the four factors is greater than 0.05 , the null hypothesis is accepted. Hence, there is no significant difference in the attitude of people towards T.V. commercials across gender. (Table6)

Since the p-value is less than 0.05 in case of Informative, Entertaining and Costly factors, the null hypothesis is rejected at 5\% significance level. Hence, there is significant difference in the attitude of people towards the T.V. commercials across the education level. In case of Annoying factor, there is no significant difference in the attitude of people towards the T.V. commercials across the level of education. (Table- 7)

Since the p-value is less than 0.05 in case of Informative, Entertaining and Costly factors, the null hypothesis is rejected at 5\% significance level. Hence, there exists a significant difference in the attitude of people towards the T.V. commercials across the present status of the respondents. In case of Annoying factor, there exists no significant difference in the attitude of people towards the T.V. commercials across the present status of the respondents. (Table- 8)

\section{Role of celebrities in T.V. Commercials and its Impact on Consumer Buying Behaviour}

Celebrities are people who have something special in them which are not common and they are known and loved by large number of people. Celebrities are people who are very popular and are followed by many people. They are well-known people like actors, sports person, singers, etc. Celebrities play a very important role in promoting the products and services of the companies. Since the celebrities are liked and followed by many people, they can be used effectively to place the products and services in the minds of the people and thus influence them to buy the same. Many people consider celebrities as their role models and thus try to imitate them by using the products and services endorsed by them. Different people might have liking for different types of celebrities like Film Stars, Sports Stars, T.V. Stars, etc. therefore it is important for the advertisers to know what type of celebrities are preferred by different categories of people and use them for advertising related type of products. This paper makes examines the type of advertisements preferred by the 
respondents, the type of celebrities preferred by them for endorsing T.V. commercials and the influence of celebrity endorsement on the purchase decision of the respondents.

Figure 2 represents the type of advertisements preferred by the respondents/consumers. Majority i.e. $67 \%$ respondents prefer both type of advertisements viz., celebrity endorsed and non-celebrity endorsed advertisements. $21 \%$ of the respondents prefer celebrity endorsed advertisements whereas $12 \%$ respondents prefer non-celebrity endorsed advertisements. Chi-Square test has been used to find if there is any relationship between type of advertisement preferred and the demographic variables.

Since the p-value (sig.) for all four demographic variables is more than 0.05 , the null hypotheses are accepted. Hence, there is no significant association between the demographic variables and the type of advertisements preferred by the respondents. (Table- 9)

Figure 3 reflects that majority of the respondents i.e. $42 \%$ respondents prefer film stars for endorsing T.V. commercials. $22 \%$ respondents prefer T.V. commercials endorsed by advertising models, $19.62 \%$ respondents prefer sports stars for endorsing the T.V. commercials and $16 \%$ respondents prefer T.V. commercials endorsed by T.V. stars.

Since the p-value (sig.) for the demographic variables age, gender and present status is less than 0.05 , the null hypothesis is rejected at 5\% significance level. Hence, there is significant association between age, gender and present status with the type of celebrities preferred for endorsing T.V. commercials. Whereas education level has p-value more than 0.05 , hence the null hypothesis is accepted. Hence, there is no significant relation with the type of celebrities preferred for endorsing T.V. commercials. (Table- 10)

Figure 4 shows the influence of celebrity endorsement on the buying decision of the respondents/consumers. More than half i.e. $60 \%$ of the respondents buying decision are not influenced by celebrity endorsement and $40 \%$ of the respondents agreed that celebrity endorsement in T.V. commercials influenced their buying decision.

Since the Pearson Chi-Square sig. (pvalue) for age is less than 0.05 , the null hypothesis is rejected. Hence, there is significant association between age and influence of celebrity endorsement on the 


\section{ELK ASIA PACIFIC JOURNAL OF MARKETING \& RETAIL MANAGEMENT}

ISSN 2349-2317 (Online); DOI: 10.16962/EAPJMRM/issn. 2349-2317/2018; Volume 9 Issue 4 (2018)

buying decision of the respondents. Gender, education and present status of the respondents have p-value more than 0.05 ; hence, the null hypothesis is accepted. Therefore, there is no significant association between the demographic variables (gender, education, and present status) with the influence of celebrity endorsement on the buying decision of the respondents. (Table- 11)

Figure 5 represents consumer attitude towards celebrity endorsed T.V. commercials. Maximum percentage of respondents i.e. $29 \%$ of the respondents feels that the celebrity endorsed T.V. commercials are entertaining, $25 \%$ of respondents are of the attitude that celebrity endorsed T.V. commercials are likable, while very close to this number $24 \%$ of the respondents feel that celebrity endorsed T.V. commercials are attention gaining. $11 \%$ of respondents were of the belief that celebrity endorsed T.V. commercials are convincing/believable whereas another $11 \%$ people felt that T.V. commercials endorsed by celebrities are impactful.

\section{Likeability of the Advertising} Appeals in T.V. Commercials Among Consumers
With the changing times, creativity and ideas projected in ads especially in T.V. commercials have changed. Earlier the focus was mainly on making emotional appeal (happy, sad) for attracting customers but now it has moved on to using fear appeal and ironic ads. Making use of humor, music, songs etc. has increased in recent times. As advertisement is an important tool for promoting the sales of the product it is important to know the attitude of people towards T.V. commercials, attitude of people/consumers towards T.V. commercials can be positive/favorable or negative/unfavorable. The use celebrity in promoting the product can have significant impact on the effectiveness of T.V. commercials. Effectiveness of T.V. commercials can also be affected by the use of different emotional, rational, humor and informative appeal, which are used in promotion of the product. Factor analysis is performed using principal component analysis. The factors were rotated using varimax rotation. The four factors identified were humorous appeal, emotional appeal, musical and rational appeal.

KMO value is 0.807 , and Bartlett's Test of Sphericity has sig. value 0.000 , which is 


\section{ELK ASIA PACIFIC JOURNAL OF MARKETING \& RETAIL MANAGEMENT}

ISSN 2349-2317 (Online); DOI: 10.16962/EAPJMRM/issn. 2349-2317/2018; Volume 9 Issue 4 (2018)

less than 0.05 . Hence, factor analysis can be carried forward. (Table- 12)

Cronbach Alpha values ranging between 0.821 and 0.887 indicate that the data is reliable. Keeping the Eigen value greater than 1 , four factors are extracted. First factor explains $30.383 \%$ of the total variance. Second, third and fourth factors explain $19.706 \%, 11.631 \%$ and $8.934 \%$ respectively. All the factors together explain $70.653 \%$ of the total variance. (Table- 13)

There is significant difference in the liking of people for humorous appeal, musical appeal and rational advertising appeal across the age groups. There is no significant difference in the liking of people towards emotional advertising appeal across the age groups. (Table- 14)

There exist a significant difference in the liking of people for humorous appeal and emotional appeal across gender. In case of Musical and Rational appeal there is no significant difference in the liking of people across gender. (Table- 15)

There is significant difference in the liking of people towards rational advertising appeal across education levels since the $p$ value is less than 0.05 . In case of
Humorous, Emotional and Musical Appeal, it can be concluded that there is no significant difference in the liking of people across the education levels since the $\mathrm{p}$-value is greater than 0.05 , the null hypothesis is accepted. (Table- 16)

There is no significant difference in the liking of people towards humorous advertising appeal, Musical advertising appeal and rational advertising appeal across the present status of respondents as the $p$ value is greater than 0.05 and the null hypothesis is accepted. In case of emotional advertising appeal, since the pvalue is less than 0.05 , the null hypothesis is rejected. Hence, there is significant difference in the liking of people towards emotional advertising appeal across the present status of respondents. (Table- 17)

\subsection{Likeability of Advertising Appeals}

Figure 6 shows a comparison between the four advertising appeals and the ranks assigned to them by the respondents. It can be seen that there is no much difference in the rankings given to the Humorous Appeal. 27.8\% respondents have given first rank to the humorous appeal, 26.8\% respondents have assigned second rank. $22 \%$ and $23.4 \%$ respondents have given third and fourth rank. A large number of 


\section{ELK ASIA PACIFIC JOURNAL OF MARKETING \& RETAIL MANAGEMENT}

ISSN 2349-2317 (Online); DOI: 10.16962/EAPJMRM/issn. 2349-2317/2018; Volume 9 Issue 4 (2018)

respondents i.e. $39.7 \%$ respondents have given fourth rank to the emotional appeal. $24.4 \%$ respondents have given third rank while $18.7 \%$ respondents given first rank to the emotional appeal. $17.2 \%$ respondents have given second rank to the emotional appeal. $30.1 \%$ respondents have given second rank to the musical appeal while $29.2 \%$ respondents have given third rank. $23.4 \%$ respondents have given first rank to the musical appeal and $17.2 \%$ have given fourth rank to the musical appeal. Majority of the respondents i.e. $30.1 \%$ respondents have given first rank to rational appeal, while second has been given by $25.8 \%$ respondents. $24.4 \%$ respondents have given third rank and $19.6 \%$ respondents have given fourth rank. Considering the first rank, highest number (i.e. 30\%) of respondents has given first rank to the rational advertising appeal. Hence it can be concluded that most number of respondents prefer rational advertising appeal over other advertising appeals. The advertising appeal preferred least by the respondents is the emotional appeal it is concluded from the fact that highest numbers (39.7\%) of respondents have given fourth rank to the emotional appeal.

\section{FINDINGS AND CONCLUSION}

This paper has made an attempt to study the consumers' attitude towards TV commercials in the state of Goa, further the role of celebrities and its impact on the consumer buying behavior has been analyzed. Also, the likeability among the advertising appeals of TV commercials has been studied. Based on the objectives formulated, data was collected and analyzed. The findings of this study are as follows: among the four mediums of advertisement i.e. television, radio, print and internet, most of the respondents prefer television as the best medium of advertisement. There exists a significant relation between medium of advertisement preferred and the demographic variables i.e. age, gender, education, and present status of the respondents.

Further, to examine the attitude of people towards T.V. commercials factor analysis has been performed using principal component analysis and four factors were identified. These are Informative factor, Entertaining factor, Annoying factor and Costly factor. It has been found that there exists a significant difference in the attitude of people towards T.V. commercials across age groups concerning the Informative, Annoying and Costly factors. Attitude of people towards TV 


\section{ELK ASIA PACIFIC JOURNAL OF MARKETING \& RETAIL MANAGEMENT}

ISSN 2349-2317 (Online); DOI: 10.16962/EAPJMRM/issn. 2349-2317/2018; Volume 9 Issue 4 (2018)

commercial has no relationship across the gender of the respondents. Analyzing the factors across education level of respondents it has been found that there exists significant difference in the attitude of people towards T.V. commercials considering the Informative, Entertaining, and Costly factor. Analyzing the factors across the present status of the respondents, the results showed that there was significant difference in the attitude of people considering the Informative, Entertaining, and Costly factor.

The role of celebrities endorsing the advertisements and its impact on the consumer buying behavior is analyzed, the findings are stated as follows: $67 \%$ of the total respondents prefer both type of advertisements i.e. celebrity endorsed as well as non-celebrity endorsed advertisements. The results also show that there is no significant association between the demographic variables and the type of advertisement preferred by the respondents. $42 \%$ out of the total respondents prefer Film Stars for endorsing T.V. commercials. There is significant association between the demographic variables (age, gender and present status) with the type of celebrities preferred for endorsing T.V. commercials.
Education levels of respondents have no relation with the type of celebrities preferred for endorsing T.V. commercials. Out of the total respondents, $60 \%$ state that, their buying decision is not influenced by the celebrity endorsing TV commercials. With respect to the demographic variables, age has significant association with the purchase decision of the respondents influenced by the celebrity endorsement whereas gender, education and present status of the respondents has no relation with the buying decision of the respondents.

This paper further studies the likeability of advertising appeals in TV commercials based on the four appeals identified, these are humorous, emotional, musical and rational appeal. There exists a significant difference in liking of people for humorous, musical and rational advertising appeals across age groups. There is significant difference in the liking of people for humorous and emotional appeal across gender. There is significant difference in the liking of people for humorous, emotional and musical advertising appeals across education level of respondents. The liking of the emotional appeal has significant difference across the present status of the respondents but the 


\section{ELK ASIA PACIFIC JOURNAL OF MARKETING \& RETAIL MANAGEMENT}

ISSN 2349-2317 (Online); DOI: 10.16962/EAPJMRM/issn. 2349-2317/2018; Volume 9 Issue 4 (2018)

liking of humorous, musical and rational appeal has no significant difference across the present status of the respondents. Rational appeal is the most preferred advertising appeal whereas emotional appeal is the least preferred advertising appeal.

\subsection{CONCLUSION}

Advertising play a very important role in communicating about the product and service to the consumers. Choosing the correct medium of advertisement for reaching the ultimate consumers is very vital as advertising products and services on any medium incurs cost, which needs to be compensated with increased revenue. Hence, the advertisers should first find an appropriate and effective medium depending upon the type of product or service and the target consumers. People belonging to different categories of age group, gender, education level, etc. may have different attitude towards the T.V. commercials, so the advertisers while designing the advertisements should consider the attitude of people and design the advertisements accordingly to make the consumers to perceive the advertisement in a positive way. Advertisers can use celebrities effectively for endorsing their products and services. Advertisers should be careful while choosing the celebrities for endorsing their products; the endorsers should be selected based on the type of product to be advertised and the based on the target customers. Similarly, advertisers can make use of various advertising appeals to attract the consumers towards their products and services. Using the correct medium of advertisement, celebrities and advertising appeals the advertisers can reach the target audience more effectively and efficiently.

\section{REFERNCES}

[1] Abirami, U., \& Krishnan, J. (2015). Endorser's Attributes and its Influence. IJ A B E R, Vol. 13, No. 1,, 37-52.

[2] Anwar, S. (April 2012). Young Consumers' Attitude towards Television Advertisements in the Internet age. International Journal of Multidisciplinary Research, Vol.2 Issue 4, 201-208.

[3] Aziz, S., Ghani, U., \& Niazi, A. (2013,). Impact of Celebrity Credibility on Advertising Effectiveness. Pakistan Journal of Commerce and Social Sciences, Vol. 7 (1), 107-127.

[4] Balakrishnan, L., \& Kumar, C. S. (May 2011). Effect of Celebrity Based Advertisements on the Purchase 
ELK ASIA PACIFIC JOURNAL OF MARKETING \& RETAIL MANAGEMENT

ISSN 2349-2317 (Online); DOI: 10.16962/EAPJMRM/issn. 2349-2317/2018; Volume 9 Issue 4 (2018)

Attitude of Consumers towards

Durable Products (A study with reference to the city of Chennai). World

Review of Business Research, Vol. 1.

No. 2., 98 - 112.

[5] Chithra, T., \& Kothai, D. (December 2014). Consumers Attitude on Television Advertisement. International Journal of Commerce, Business and Management (IJCBM), Vol. 3, No.6, 819-823.

[6] Chittithaworn, C., Islam, M. A., \& Thooksoon, O. (February 2011). Belief Dimensions and Viewer's Attitude towards. International Journal of Marketing Studies, Vol. 3, No. 1, 95102.

[7] ERTIKE, A. S. (January 2011). 17-25 Year Old Turkish College Students' Attitude Towards TV Advertisements. International Journal of Business and Social Science, Vol. 2 No. 3 , 201-203.

[8] Farooq, Q., Shafique, N., Khurshid, M. M., \& Ahmad, N. (2015). Impact of comic factor in tv ads on buying behavior of university students. International Letters of Social and Humanistic Sciences, Vol. 49 (2015) 12-20, 12-20.

[9] Guo, G., Cheung, F. S.-L., Leung, W.F., \& Chow, C. W.-C. (April 2008).
Attitude towards TV Advertising:. Journal of Chinese Marketing, Vol.1, 60-66.

[10] Hudha, A. N., \& Hidayat, A.

(Desember 2009). Study of Consumer Attitudes toward Television. Jurnal

Siasat Bisnis, Vol. 13 No. 3, 217-232.

[11] Kumar, V., \& Hundal, D. S. (September 2015). Customer

Perception towards Celebrity

Endorsement. Pacific Business Review International, Volume 8, Issue 5,, 4653.

[12] Liligeto, R., Singh, G., \& Naz, R. (2014). Factors influencing Consumer Perception (CP) towards TV and Newspaper Advertising. The Journal of Pacific Studies, Volume 34 Issue 2, 6386.

[13] Lin, L.-Y. ( 2011). The impact of advertising appeals and advertising spokespersons on advertising attitudes and purchase intentions. African Journal of Business Management, Vol. 5(21), 8446-8457.

[14] Ling, K. C., Piew, T. H., \& Chai, L. T. (2010). The Determinants of Consumers' Attitude Towards Advertising. CANADIAN SOCIAL SCIENCE, Vol. 6, No. 4, 114-126. 
ELK ASIA PACIFIC JOURNAL OF MARKETING \& RETAIL MANAGEMENT

ISSN 2349-2317 (Online); DOI: 10.16962/EAPJMRM/issn. 2349-2317/2018; Volume 9 Issue 4 (2018)

[15] Mensah, P. A., Asuamah, S. Y., \&

Amankwah, J. (April 2013).

Consumer's Attitude towards

Advertisement Elements: A Survey of

Marketing Students in Sunyani

Polytechnic, Ghana, West Africa.

International journal of Innovative

Research in Management, volume

4(issue 2), 13-24.

[16] Parmar, B. J., \& Patel, R. P. (n.d.). A

study on consumer perception for

celebrity \& non celebrity endorsement

in television commercials for fast

moving consumer goods. Global

Business and Economics Research

Journal, Vol. 3 (2): 1 - 11, 1-11.

[17] Pughazhendi, A., Thirunavukkarasu,

R., \& Susendiran, S. (December 2011).

A Study on Celebrity Based Advertisements on the Purchase Attitude of Consumers towards Durable Products in Coimbatore city, Tamil Nadu, India. Journal of Marketing and Management, Vol. 1 No. 1, 16-27.

[18] Radha, G., \& P, J. (November 2013). Influence of Celebrity Endorsement on the Consumer's Purchase Decision. International Journal of Scientific and Research Publications,, Volume 3, Issue 11, 1-28.
[19] Rashid, M. A., Nallamuthu, J., \& Sidin, S. M. (2002). Perceptions of Advertising and Celebrity. Asia Pacific Management Review, 7(4), 535-554.

[20] Razzaque, M. A. (2009). Attitude towards TV Advertisements: The Case of the Bangladeshi Tween-agers. ANZMAC, 1-7.

[21] Rizwan, M., Pirzada, S., Sohail, A., Nadeem, M., \& Murid, W. (n.d.). The Role of Advertising Appeals, Role of Celebrity \& Expert in T.V Advertising Attitude. IOSR Journal of Business and Management (IOSR-JBM), ISSN:23197668, 52-57.

[22] Usman, M., Ilyas, S., Hussain, M. F., \& Qureshi, T. M. (November 2010). General Attitude towards Advertising: Cultural Influence in Pakistan. International Journal of Marketing Studies, Vol. 2, No. 2, 124-133.

[23] Yarahmadi, F. (2015). Perception Differences Towards TV Commercials: A Gender Comparison in Iran. World Engineering \& Applied Sciences Journal , 6 (1): 01-08, 1-8.

[24] Yasin, S., Anwar , S., \& Sajid, M. (2013). Consumer Attitude towards TV Advertising Based Upon Consumer Age \& Gender. Information 
and Knowledge Management, Vol.3,

No.2, 163-172.

\section{LIST OF TABLES}

\begin{tabular}{|c|c|c|c|}
\hline \multicolumn{4}{|c|}{ Table 1: Demographic Profile of Respondents } \\
\hline Demographic Variables & Options & Frequency & Percent \\
\hline \multirow{7}{*}{ Age } & $15-20$ & 18 & 8.6 \\
\hline & $21-25$ & 82 & 39.2 \\
\hline & $26-30$ & 29 & 13.9 \\
\hline & $31-35$ & 29 & 13.9 \\
\hline & $36-40$ & 16 & 7.7 \\
\hline & $41-45$ & 16 & 7.7 \\
\hline & Above 46 & 19 & 9.1 \\
\hline \multirow[b]{3}{*}{ Gender } & Options & Frequency & Percent \\
\hline & Male & 76 & 36.4 \\
\hline & Female & 133 & 63.6 \\
\hline \multirow{8}{*}{ Education } & Options & Frequency & Percent \\
\hline & Less than 10th & 22 & 10.5 \\
\hline & $10-12$ th & 32 & 15.3 \\
\hline & Graduation & 71 & 34 \\
\hline & Post-Graduation & 53 & 25.4 \\
\hline & Professional Degree & 23 & 11 \\
\hline & Doctorate & 1 & 0.5 \\
\hline & Others & 7 & 3.3 \\
\hline \multirow{6}{*}{ Present Status } & Options & Frequency & Percent \\
\hline & Student & 81 & 38.8 \\
\hline & Working Class & 85 & 40.7 \\
\hline & Home Maker & 31 & 14.8 \\
\hline & Unemployed & 9 & 4.3 \\
\hline & Retired & 2 & 1 \\
\hline
\end{tabular}


ELK ASIA PACIFIC JOURNAL OF MARKETING \& RETAIL MANAGEMENT

ISSN 2349-2317 (Online); DOI: 10.16962/EAPJMRM/issn. 2349-2317/2018; Volume 9 Issue 4 (2018)

\begin{tabular}{|l|l|l|l|}
\hline & Others & 1 & 0.5 \\
\hline Source: Field Survey & & \\
\hline
\end{tabular}

Table 2:

Chi-Square Test for Medium of Advertisement Preferred Across

Demographic Variables

\begin{tabular}{|c|c|c|c|c|}
\hline Demographics & Age & Gender & Education & Present Status \\
\hline Value & $62.189^{*}$ & $23.626^{*}$ & $42.383^{*}$ & $43.555^{*}$ \\
\hline Asymp. Sig. (2-sided) & 0.000 & 0.000 & 0.012 & 0.002 \\
\hline
\end{tabular}

Table 3: KMO and Bartlett's Test

\begin{tabular}{|l|l|l|}
\hline \multicolumn{2}{|l|}{ Kaiser-Meyer-Olkin Measure of Sampling Adequacy. } & .747 \\
\hline Bartlett's Test of Sphericity & Approx. Chi-Square & 1289.299 \\
\cline { 2 - 3 } & df & 91 \\
\hline
\end{tabular}

Table 4: Rotated Factor Structure of the Values Used in the Study

\begin{tabular}{|l|l|l|l|l|l|}
\hline Sr. & \multicolumn{1}{|c|}{ Statements } & No. & & & \\
\hline 7 & T.V. commercials help me in my buying decision & .703 & & \\
\hline 8 & $\begin{array}{l}\text { T.V. commercials help me in making product } \\
\text { comparison }\end{array}$ & .843 & & & \\
\hline 9 & $\begin{array}{l}\text { T.V. commercials are a good source of information } \\
\text { on products and services }\end{array}$ & .719 & & \\
\hline 10 & $\begin{array}{l}\text { T.V. commercials give up to date information on } \\
\text { emerging products and services }\end{array}$ & .734 & & & \\
\hline 11 & $\begin{array}{l}\text { T.V. commercials are reliable in making buying } \\
\text { decision }\end{array}$ & .823 & & & \\
\hline 12 & Information provided in T.V. commercial can be & .753 & & & \\
\hline
\end{tabular}


ELK ASIA PACIFIC JOURNAL OF MARKETING \& RETAIL MANAGEMENT

ISSN 2349-2317 (Online); DOI: 10.16962/EAPJMRM/issn. 2349-2317/2018; Volume 9 Issue 4 (2018)

\begin{tabular}{|c|c|c|c|c|c|}
\hline & relied upon for making product comparison & & & & \\
\hline 3 & T.V. commercials are good form of entertainment & & 677 & & \\
\hline 4 & $\begin{array}{l}\text { T.V. commercials are more entertaining than other } \\
\text { contents on T.V. }\end{array}$ & & .699 & & \\
\hline 5 & $\begin{array}{l}\text { Various advertising elements (emotion, humor, } \\
\text { music etc.) used in T.V. commercials makes the } \\
\text { adds very entertaining to watch }\end{array}$ & & .736 & & \\
\hline 6 & $\begin{array}{l}\text { T.V. commercials are more entertaining than other } \\
\text { forms of advertisements (radio, newspaper, etc.) }\end{array}$ & & .657 & & \\
\hline 13 & T.V. commercials are very annoying and irritating & & & .910 & \\
\hline 14 & T.V. commercials are a waste of time & & & .898 & \\
\hline 1 & $\begin{array}{l}\text { Advertising products and services on television } \\
\text { incur huge cost which are added to the product thus } \\
\text { making it expensive }\end{array}$ & & & & .907 \\
\hline 2 & $\begin{array}{l}\text { Celebrity endorsement in T.V. commercial ads } \\
\text { additional cost to products and services which } \\
\text { makes them very expensive to buy }\end{array}$ & & & & .905 \\
\hline & Cronbach's Alpha & .869 & .689 & .863 & .860 \\
\hline & Eigenvalue & 4.314 & 2.469 & 1.630 & 1.162 \\
\hline & \% of Variance Explained & 30.815 & $\mathbf{1 7 . 6 3 5}$ & 11.640 & 8.302 \\
\hline & Cumulative Variance Explained & 30.815 & 48.449 & 60.089 & 68.391 \\
\hline
\end{tabular}

Table 5: One-Way ANOVA for Consumer Attitude across Age Groups

\begin{tabular}{|c|l|c|c|c|c|c|}
\hline Factors & & $\begin{array}{c}\text { Sum of } \\
\text { Squares }\end{array}$ & $\begin{array}{c}\text { df } \\
\text { Informative }\end{array}$ & $\begin{array}{c}\text { Mean } \\
\text { Square }\end{array}$ & F & Sig. \\
\hline & Between Groups & 11.079 & 6 & 1.846 & $3.124^{*}$ & .006 \\
\cline { 2 - 8 } & Within Groups & 119.375 & 202 & .591 & & \\
\cline { 2 - 8 } & Total & 130.454 & 208 & & & \\
\hline & Between Groups & 6.870 & 6 & 1.145 & 2.079 & .057 \\
\hline
\end{tabular}


ELK ASIA PACIFIC JOURNAL OF MARKETING \& RETAIL MANAGEMENT

ISSN 2349-2317 (Online); DOI: 10.16962/EAPJMRM/issn. 2349-2317/2018; Volume 9 Issue 4 (2018)

\begin{tabular}{|c|l|c|c|c|c|c|}
\hline Entertaining & Within Groups & 111.238 & 202 & .551 & & \\
\cline { 2 - 7 } Annoying & Total & 118.108 & 208 & & & \\
\cline { 2 - 8 } & Between Groups & 11.387 & 6 & 1.898 & $2.288^{*}$ & .037 \\
\cline { 2 - 8 } & Within Groups & 167.582 & 202 & .830 & & \\
\cline { 2 - 8 } & Total & 178.969 & 208 & & & \\
\hline & Between Groups & 17.496 & 6 & 2.916 & $3.206^{*}$ & .005 \\
& Within Groups & 183.753 & 202 & .910 & & \\
& Total & 201.249 & 208 & & & \\
\hline
\end{tabular}

Table 6: One-Way ANOVA for Consumer Attitude across Gender

\begin{tabular}{|c|l|c|c|c|c|c|}
\hline Factors & & $\begin{array}{c}\text { Sum of } \\
\text { Squares }\end{array}$ & df & $\begin{array}{c}\text { Mean } \\
\text { Square }\end{array}$ & F & Sig. \\
\hline \multirow{5}{*}{ Informative } & Between Groups & .157 & 1 & .157 & .250 & .618 \\
\cline { 2 - 8 } & Within Groups & 130.297 & 207 & .629 & & \\
\cline { 2 - 8 } & Total & 130.454 & 208 & & & \\
\hline \multirow{3}{*}{ Annoying } & Between Groups & .049 & 1 & .049 & .087 & .769 \\
\cline { 2 - 8 } & Within Groups & 118.058 & 207 & .570 & & \\
\cline { 2 - 8 } & Total & 118.108 & 208 & & & \\
\hline & Between Groups & .144 & 1 & .144 & .166 & .684 \\
\hline & Total & 178.825 & 207 & .864 & & \\
\hline \multirow{2}{*}{ Costly } & Between Groups & .700 & 1 & .700 & .722 & .396 \\
\cline { 2 - 8 } & Within Groups & 200.549 & 207 & .969 & & \\
\cline { 2 - 8 } & Total & 201.249 & 208 & & & \\
\hline
\end{tabular}


Table 7: One-Way ANOVA for Consumer Attitude across Education Levels

\begin{tabular}{|c|l|c|r|r|r|c|}
\hline Factors & & $\begin{array}{r}\text { Sum of } \\
\text { Squares }\end{array}$ & $\begin{array}{r}\text { Mean } \\
\text { Square }\end{array}$ & F & Sig. \\
\hline \multirow{3}{*}{ Informative } & Between Groups & 8.857 & 6 & 1.476 & $2.452^{*}$ & .026 \\
\cline { 2 - 8 } & Within Groups & 121.597 & 202 & .602 & & \\
\cline { 2 - 8 } & Total & 130.454 & 208 & & & \\
\hline \multirow{3}{*}{ Annoying } & Between Groups & 7.280 & 6 & 1.213 & $2.212^{*}$ & .043 \\
\cline { 2 - 8 } & Within Groups & 110.827 & 202 & .549 & & \\
& Total & 118.108 & 208 & & & \\
\hline \multirow{2}{*}{ Costly } & Wetween Groups & 5.399 & 6 & .900 & 1.047 & .396 \\
\cline { 2 - 8 } & Wotal & 173.570 & 202 & .859 & & \\
\hline & Between Groups & 178.969 & 208 & & & \\
\hline & Within Groups & 183.451 & 6 & 2.909 & $3.197^{*}$ & .005 \\
\hline
\end{tabular}

Table 8: One-Way ANOVA for Consumer Attitude across Present Status

\begin{tabular}{|c|l|c|c|c|c|c|}
\hline Factors & & $\begin{array}{c}\text { Sum of } \\
\text { Squares }\end{array}$ & df & $\begin{array}{c}\text { Mean } \\
\text { Square }\end{array}$ & F & Sig. \\
\hline \multirow{3}{*}{ Informative } & Between Groups & 13.096 & 5 & 2.619 & $4.530^{*}$ & .001 \\
\cline { 2 - 8 } & Within Groups & 117.358 & 203 & .578 & & \\
\cline { 2 - 8 } Entertaining & Total & 130.454 & 208 & & & \\
\hline & Between Groups & 6.340 & 5 & 1.268 & $2.303^{*}$ & .046 \\
\cline { 2 - 8 } & Within Groups & 111.768 & 203 & .551 & & \\
\hline & Total & 118.108 & 208 & & & \\
\hline & Between Groups & 9.281 & 5 & 1.856 & 2.220 & .054 \\
\hline
\end{tabular}


ELK ASIA PACIFIC JOURNAL OF MARKETING \& RETAIL MANAGEMENT ISSN 2349-2317 (Online); DOI: 10.16962/EAPJMRM/issn. 2349-2317/2018; Volume 9 Issue 4 (2018)

\begin{tabular}{|c|l|c|c|c|c|c|}
\hline Annoying & Within Groups & 169.688 & 203 & .836 & & \\
\cline { 2 - 8 } & Total & 178.969 & 208 & & & \\
\hline \multirow{3}{*}{ Costly } & Between Groups & 16.047 & 5 & 3.209 & $3.518^{*}$ & .005 \\
\cline { 2 - 8 } & Within Groups & 185.202 & 203 & .912 & & \\
\cline { 2 - 7 } & Total & 201.249 & 208 & & & \\
\hline
\end{tabular}

Table 9: Chi-Square Test for Type of Advertisement Preferred across Demographic Variables

\begin{tabular}{|l|c|c|c|c|}
\hline \multicolumn{1}{|c|}{ Demographics } & Age & Gender & Education & Present Status \\
\hline Value & 15.335 & 0.548 & 12.628 & 10.534 \\
\hline Asymp. Sig. (2-sided) & 0.224 & 0.760 & 0.397 & 0.395 \\
\hline
\end{tabular}

Table 10: Chi-Square Test for Type of Celebrity Preferred for Endorsing T.V.

\section{Commercials}

\begin{tabular}{|l|l|l|l|l|}
\hline Demographics & Age & Gender & Education & $\begin{array}{l}\text { Present } \\
\text { Status }\end{array}$ \\
\hline Value & $41.507^{*}$ & $45.081^{*}$ & 27.303 & $42.951^{*}$ \\
\hline Asymp. Sig. (2-sided) & 0.001 & 0.000 & 0.073 & 0.000 \\
\hline
\end{tabular}

Table 11: Chi-Square Test for Influence of Celebrity Endorsement on the Buying Decision of Consumers across Demographic Variables

\begin{tabular}{|l|l|l|l|l|}
\hline \multicolumn{1}{|c|}{ Demographics } & \multicolumn{1}{c|}{ Age } & Gender & Education & Present Status \\
\hline Value & $27.958^{*}$ & 1.043 & 8.329 & 10.152 \\
\hline Asymp. Sig. (2-sided) & 0.006 & 0.594 & 0.759 & 0.427 \\
\hline
\end{tabular}

Table 12: KMO and Bartlett's Test 
ELK ASIA PACIFIC JOURNAL OF MARKETING \& RETAIL MANAGEMENT

ISSN 2349-2317 (Online); DOI: 10.16962/EAPJMRM/issn. 2349-2317/2018; Volume 9 Issue 4 (2018)

\begin{tabular}{|l|l|r|}
\hline Kaiser-Meyer-Olkin Measure of Sampling Adequacy. & .807 \\
\hline \multirow{3}{*}{ Bartlett's Test of Sphericity } & Approx. Chi-Square & 1713.110 \\
\cline { 2 - 3 } & df & 120 \\
\cline { 2 - 3 } & Sig. & .000 \\
\hline
\end{tabular}

Table 13: Rotated Factor Structure of the Values Used in the Study

\begin{tabular}{|c|c|c|c|c|c|}
\hline $\begin{array}{l}\text { Sr. } \\
\text { No. }\end{array}$ & Statements & 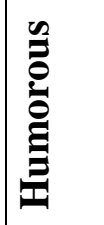 & & 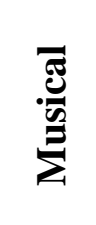 & 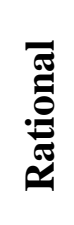 \\
\hline 5 & Humorous T.V. commercials are very entertaining & .786 & & & \\
\hline 6 & $\begin{array}{l}\text { I feel that T.V. commercials that use humor/jokes in them are very } \\
\text { creative }\end{array}$ & .877 & & & \\
\hline 7 & $\begin{array}{l}\text { Humor/jokes in the T.V. commercials helps me forget my stress for } \\
\text { some time and relax }\end{array}$ & .795 & & & \\
\hline 8 & $\begin{array}{l}\text { The humor/joke element used in the T.V. commercial helps me to } \\
\text { remember the advertisement for longer time }\end{array}$ & .707 & & & \\
\hline 9 & $\begin{array}{l}\text { Humorous T.V. commercials are more entertaining and attractive } \\
\text { than any other appeals in the T.V. commercial }\end{array}$ & .799 & & & \\
\hline 10 & $\begin{array}{l}\text { I like the family/friends relationships shown in the T.V. } \\
\text { commercials }\end{array}$ & & .778 & & \\
\hline 11 & $\begin{array}{l}\text { Family relationships shown in the T.V. commercials helps me } \\
\text { connect with my family }\end{array}$ & & .885 & & \\
\hline 12 & $\begin{array}{l}\text { I remember the time with my friends when I see some advertisings } \\
\text { that show friends bonding/relationships }\end{array}$ & & .774 & & \\
\hline 13 & $\begin{array}{l}\text { Family emotions shown in T.V. commercials have a lasting impact } \\
\text { on me and also influence my buying decision }\end{array}$ & & .803 & & \\
\hline 1 & $\begin{array}{l}\text { I like those T.V. commercials which makes use of music/jingles in } \\
\text { them }\end{array}$ & & & .816 & \\
\hline 2 & Those T.V. commercials that make use of old songs makes me feel & & & .803 & \\
\hline
\end{tabular}


ELK ASIA PACIFIC JOURNAL OF MARKETING \& RETAIL MANAGEMENT

ISSN 2349-2317 (Online); DOI: 10.16962/EAPJMRM/issn. 2349-2317/2018; Volume 9 Issue 4 (2018)

\begin{tabular}{|c|c|c|c|c|c|}
\hline & happy and attract me & & & & \\
\hline 3 & $\begin{array}{l}\text { The jingle used in the T.V. commercial helps me recollect the ad } \\
\text { and also to remember the product/brand }\end{array}$ & & & .721 & \\
\hline 4 & $\begin{array}{l}\text { Music or song used in T.V. commercial makes me feel connected } \\
\text { to the ad/product and makes me feel good }\end{array}$ & & & .796 & \\
\hline 14 & $\begin{array}{l}\text { Rational/informational advertisements helps me to make informed } \\
\text { decisions }\end{array}$ & & & & .835 \\
\hline 15 & $\begin{array}{l}\text { Rational advertisements helps me to compare products/services } \\
\text { across various brands }\end{array}$ & & & & .876 \\
\hline \multirow[t]{5}{*}{16} & Rational advertisements gives better price comparisons & & & & .866 \\
\hline & Cronbach's Alpha & .867 & .842 & .821 & .887 \\
\hline & Eigenvalue & 4.86 & 3.15 & 1.86 & 1.42 \\
\hline & \% of Variance Explained & 30.38 & 19.70 & 11.6 & 8.93 \\
\hline & Cumulative Variance Explained & 30.38 & 50.08 & 61.7 & $\overline{70.6}$ \\
\hline
\end{tabular}

Table 14:One-Way ANOVA for Peoples Liking for various Advertising Appeals across Age Groups

\begin{tabular}{|l|l|l|l|l|l|l|}
\hline \multicolumn{1}{|c|}{ Factors } & & $\begin{array}{c}\text { Sum of } \\
\text { Squares }\end{array}$ & df & $\begin{array}{c}\text { Mean } \\
\text { Square }\end{array}$ & F & Sig. \\
\hline \multirow{3}{*}{ Humorous } & Between Groups & 11.615 & 6 & 1.936 & $2.509^{*}$ & .023 \\
\cline { 2 - 8 } & Within Groups & 155.838 & 202 & .771 & & \\
\cline { 2 - 9 } & Total & 167.452 & 208 & & & \\
\hline \multirow{3}{*}{ Musical } & Between Groups & 9.350 & 6 & 1.558 & 1.765 & .108 \\
\cline { 2 - 9 } & Within Groups & 178.323 & 202 & .883 & & \\
\hline \multirow{3}{*}{ Rational } & Total & 187.673 & 208 & & & \\
\hline & Between Groups & 10.241 & 6 & 1.707 & $2.149^{*}$ & .049 \\
\cline { 2 - 9 } & Within Groups & 160.433 & 202 & .794 & & \\
\cline { 2 - 9 } & Total & 170.674 & 208 & & & \\
\hline
\end{tabular}


ELK ASIA PACIFIC JOURNAL OF MARKETING \& RETAIL MANAGEMENT

ISSN 2349-2317 (Online); DOI: 10.16962/EAPJMRM/issn. 2349-2317/2018; Volume 9 Issue 4 (2018)

Table 15: One-Way ANOVA for Peoples Liking for various Advertising Appeals across Gender

\begin{tabular}{|l|l|l|l|l|l|l|}
\hline \multirow{3}{*}{ Factors } & \multicolumn{1}{|c|}{$\begin{array}{c}\text { Sum of } \\
\text { Squares }\end{array}$} & \multicolumn{1}{|c|}{$\mathbf{d f}$} & $\begin{array}{c}\text { Mean } \\
\text { Square }\end{array}$ & \multicolumn{1}{|c|}{ F } & Sig. \\
\hline \multirow{4}{*}{ Humorous } & Between Groups & 9.142 & 1 & 9.142 & $11.954^{*}$ & .001 \\
\cline { 2 - 8 } & Within Groups & 158.310 & 207 & .765 & & \\
\cline { 2 - 8 } & Total & 167.452 & 208 & & & \\
\hline \multirow{3}{*}{ Emotional } & Between Groups & 15.226 & 1 & 15.226 & $18.277^{*}$ & .000 \\
\cline { 2 - 8 } & Within Groups & 172.447 & 207 & .833 & & \\
\cline { 2 - 8 } & Total & 187.673 & 208 & & & \\
\cline { 2 - 8 } & Between Groups & .001 & 1 & .001 & .001 & .980 \\
\cline { 2 - 8 } & Total & 170.674 & 207 & .825 & & \\
\hline \multirow{3}{*}{ Rational } & Between Groups & .088 & 1 & .088 & .112 & .738 \\
\cline { 2 - 8 } & Within Groups & 162.033 & 207 & .783 & & \\
\cline { 2 - 8 } & Total & 162.121 & 208 & & & \\
\hline
\end{tabular}

Table 16: One-Way ANOVA for Peoples Liking for various Advertising Appeals across Education Levels

\begin{tabular}{|c|l|l|l|l|l|l|}
\hline \multirow{2}{*}{ Factors } & & \multicolumn{1}{|c|}{$\begin{array}{c}\text { Sum of } \\
\text { Squares }\end{array}$} & df & $\begin{array}{c}\text { Mean } \\
\text { Square }\end{array}$ & F & Sig. \\
\hline \multirow{3}{*}{ Humorous } & Between Groups & 7.114 & 6 & 1.186 & 1.494 & .182 \\
\cline { 2 - 8 } & Within Groups & 160.338 & 202 & .794 & & \\
\cline { 2 - 8 } & Total & 167.452 & 208 & & & \\
\hline \multirow{2}{*}{ Emotional } & Between Groups & 9.261 & 6 & 1.543 & 1.748 & .112 \\
\cline { 2 - 8 } & Within Groups & 178.412 & 202 & .883 & & \\
\hline
\end{tabular}


ELK ASIA PACIFIC JOURNAL OF MARKETING \& RETAIL MANAGEMENT

ISSN 2349-2317 (Online); DOI: 10.16962/EAPJMRM/issn. 2349-2317/2018; Volume 9 Issue 4 (2018)

\begin{tabular}{|l|l|l|l|l|l|l|}
\hline & Total & 187.673 & 208 & & & \\
\hline \multirow{4}{*}{ Musical } & Between Groups & 5.095 & 6 & .849 & 1.036 & .403 \\
\cline { 2 - 8 } & Within Groups & 165.579 & 202 & .820 & & \\
\cline { 2 - 7 } & Total & 170.674 & 208 & & & \\
\hline \multirow{3}{*}{ Rational } & Between Groups & 14.186 & 6 & 2.364 & $3.228^{*}$ & .005 \\
\cline { 2 - 8 } & Within Groups & 147.936 & 202 & .732 & & \\
\hline
\end{tabular}

Table 17: One-Way ANOVA for Peoples Liking for various Advertising Appeals across Present Status

\begin{tabular}{|c|c|c|c|c|c|c|}
\hline Factors & & $\begin{array}{l}\text { Sum of } \\
\text { Squares }\end{array}$ & df & $\begin{array}{c}\text { Mean } \\
\text { Square }\end{array}$ & $\mathbf{F}$ & Sig. \\
\hline \multirow{3}{*}{ Humorous } & Between Groups & 7.463 & 5 & 1.493 & 1.894 & .097 \\
\hline & Within Groups & 159.990 & 203 & .788 & & \\
\hline & Total & 167.452 & 208 & & & \\
\hline \multirow{3}{*}{ Emotional } & Between Groups & 14.883 & 5 & 2.977 & $3.497 *$ & .005 \\
\hline & Within Groups & 172.790 & 203 & .851 & & \\
\hline & Total & 187.673 & 208 & & & \\
\hline \multirow{3}{*}{ Musical } & Between Groups & 5.582 & 5 & 1.116 & 1.373 & .236 \\
\hline & Within Groups & 165.092 & 203 & .813 & & \\
\hline & Total & 170.674 & 208 & & & \\
\hline \multirow{3}{*}{ Rational } & Between Groups & 8.308 & 5 & 1.662 & 2.193 & .056 \\
\hline & Within Groups & 153.813 & 203 & .758 & & \\
\hline & Total & 162.121 & 208 & & & \\
\hline
\end{tabular}




\section{LIST OF FIGURES}

Figure 1: Medium of Advertisement Preferred

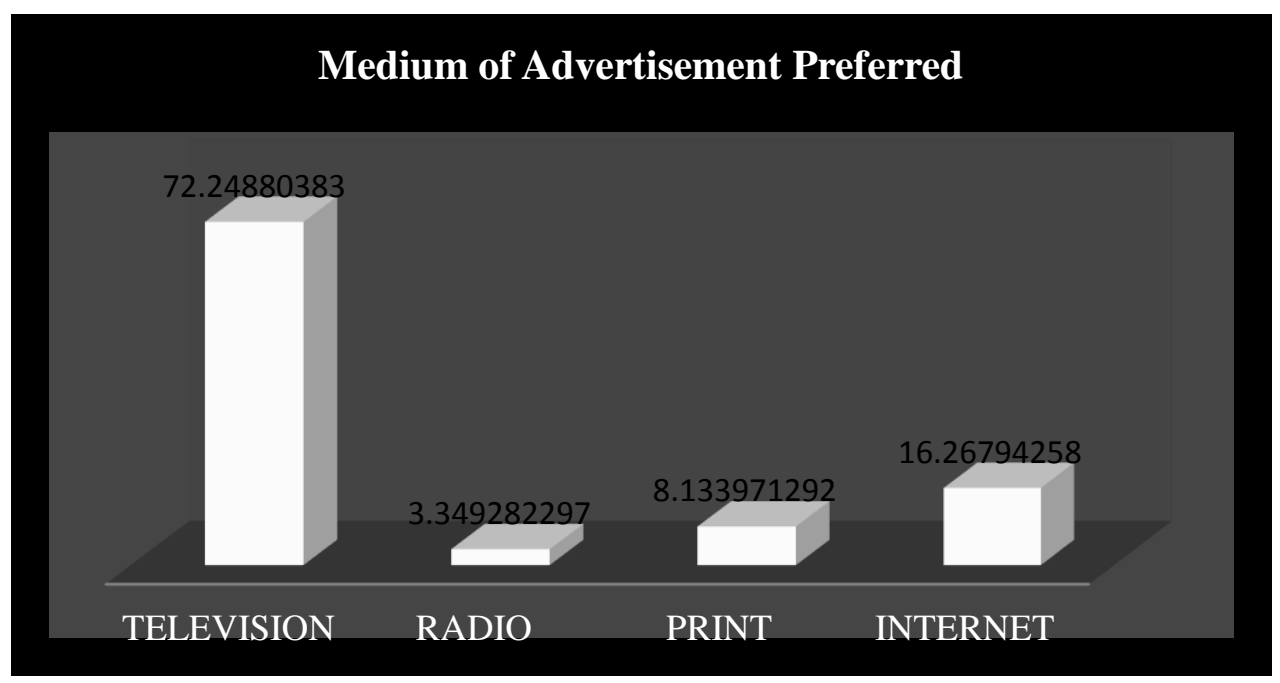

Source: Field Survey

Figure 2: Type of Advertisement Preferred by the Consumers

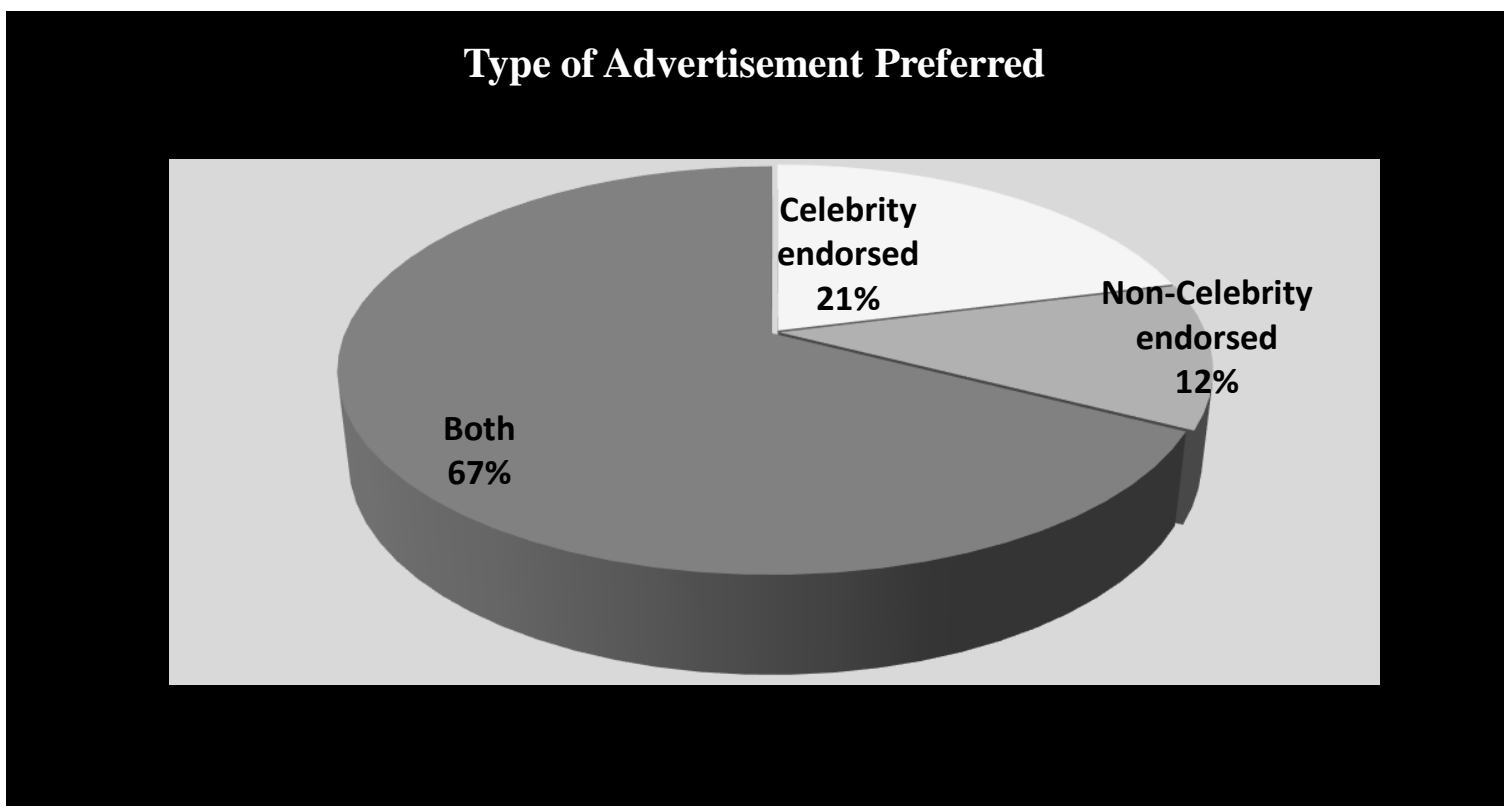

Source: Field Survey

Figure 3: Type of Celebrities Preferred for Endorsing T.V. Commercials 


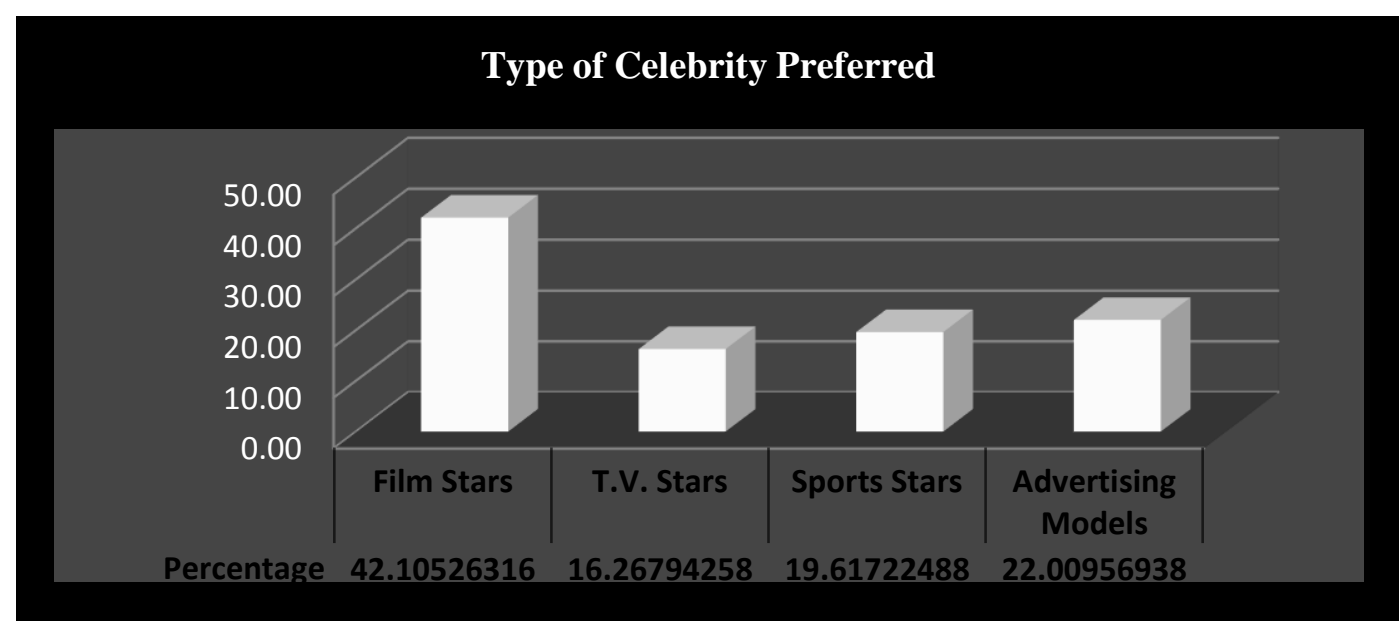

Source: Field Survey

Figure 4: Influence of Celebrity Endorsement on Buying Decision of the Consumers

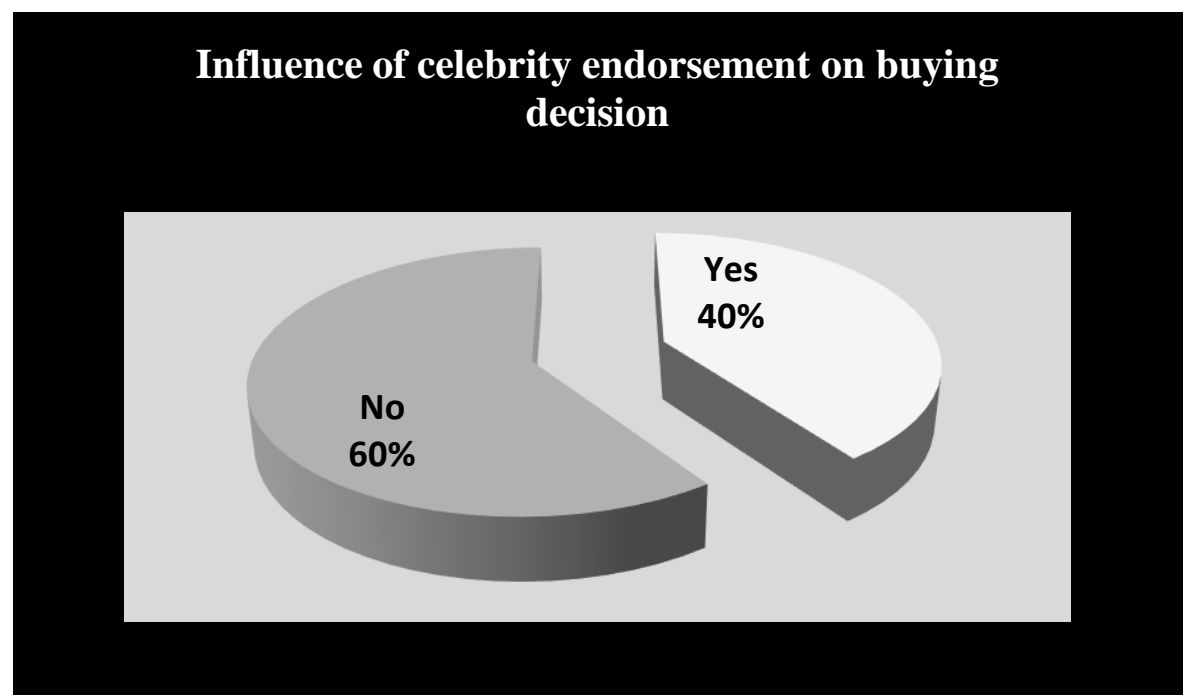

Source: Field Survey 
ELK ASIA PACIFIC JOURNAL OF MARKETING \& RETAIL MANAGEMENT

ISSN 2349-2317 (Online); DOI: 10.16962/EAPJMRM/issn. 2349-2317/2018; Volume 9 Issue 4 (2018)

Figure 5: Consumer Attitude towards Celebrity Endorsed T.V. Commercials

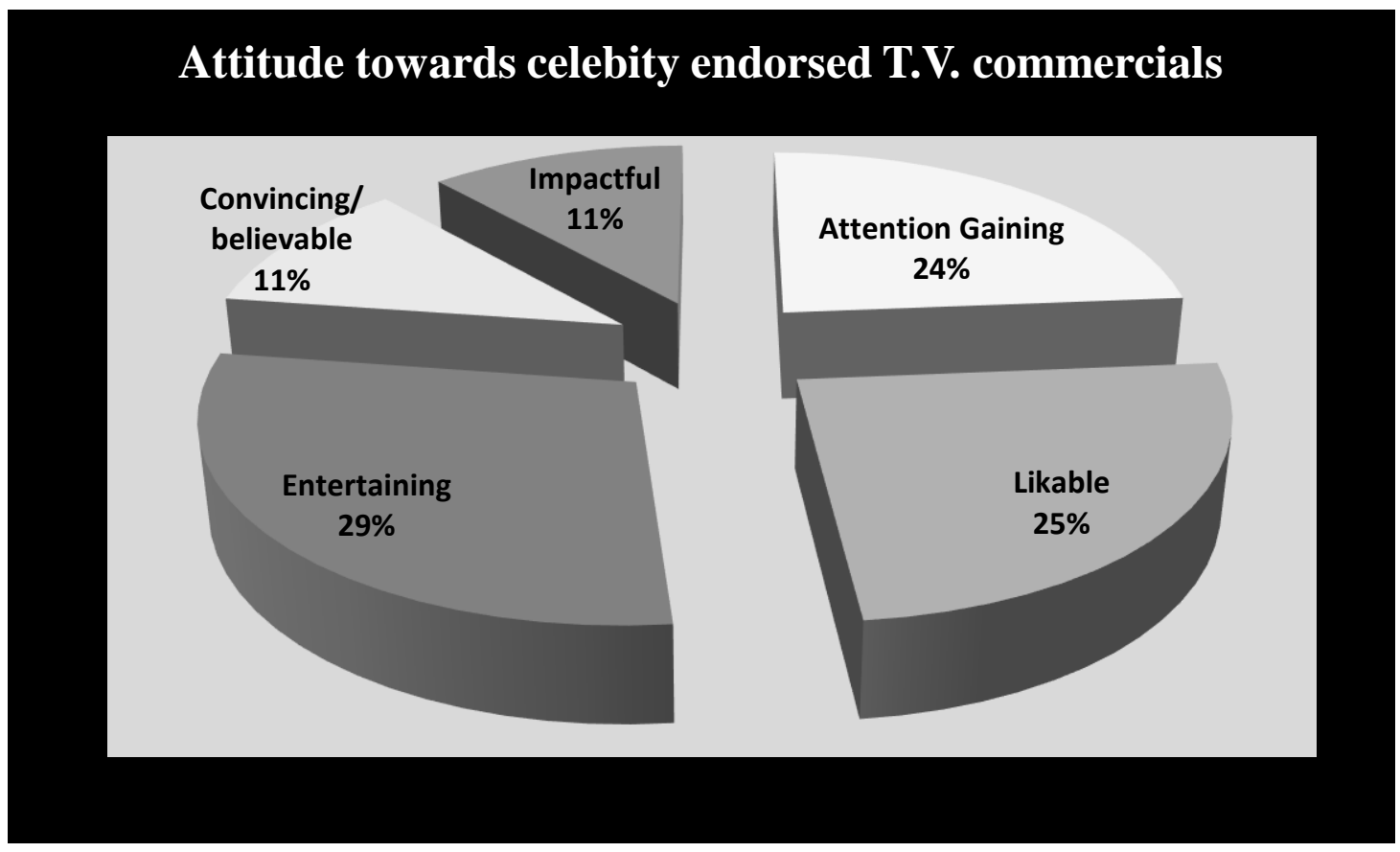

Source: Field Survey

Figure 6: Likeability of Advertising Appeals

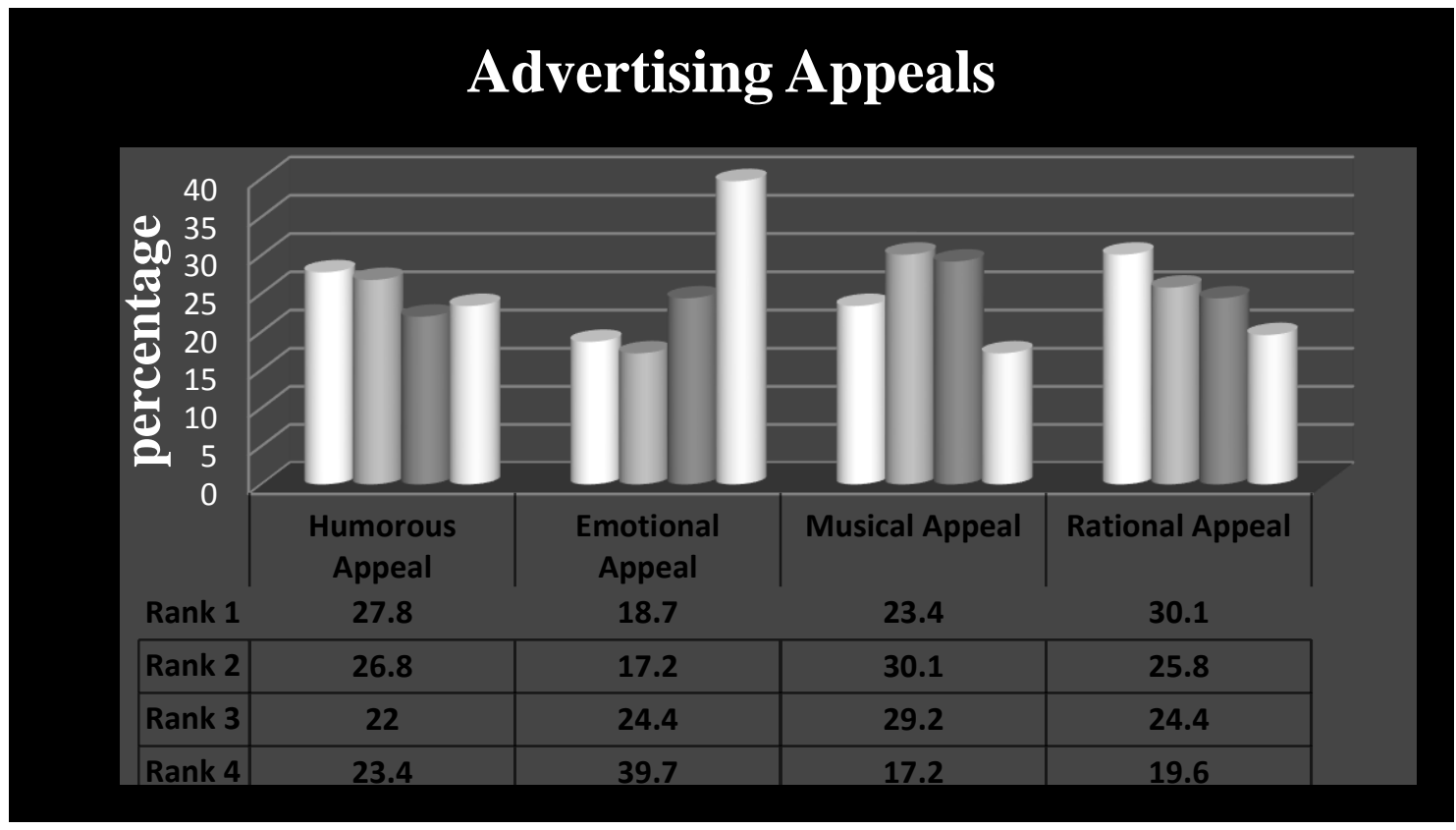

Source: Field Survey 